\title{
The Implementation of Arabic Utilization as a Course Language in Islamic Subjects
}

\author{
Wahyudi Buska*, Yogia Prihartini \\ Faculty of Islamic Education and Teacher Training \\ Sulthan Thaha Saifuddin State Islamic University \\ Jambi, Indonesia \\ *wahyudi@uinjambi.ac.id
}

\author{
Kasful Anwar Us, Ahmad Syukri, Diana Rozelin \\ Postgraduate of \\ Sulthan Thaha Saifuddin State Islamic University \\ Jambi, Indonesia
}

\begin{abstract}
This study aims to describe the application of Arabic as the language of instruction in Islamic subjects at the Sulthan Thaha Saifuddin State Islamic University of Jambi. This research is qualitative research, and the data was collected using observation, interview, documentation, and questionnaires. The findings showed that Arabic cannot be applied to the maximum and only a few lecturers have started to implement it even though it is not in full. The models of Islamic subject lecturers using Arabic as the language of instruction vary greatly. Some constraints were faced in the use of Arabic as the language of instruction in Islamic subjects, including various abilities of students, lecturers' lack of ability to speak Arabic actively, limited books and literature on Islamic subjects in Arabic, and lack of training to improve the skills of lecturers who teach Islamic subjects. The implementation of Arabic as an introductory language of Islamic subjects has not been effective.
\end{abstract}

Keywords-implementation, Arabic, course language, Islamic subjects

\section{INTRODUCTION}

The Sulthan Thaha Saifuddin State Islamic University of Jambi is one of the state Islamic higher education institutions that requires all students, of any department, to take Arabic lecture for a full year. The program aims to have all students at the Sulthan Thaha Saifuddin State Islamic University of Jambi acquire a receptive and productive Arabic language skills. They are actively expected to be able to converse with Arabic in daily life, and at the same time they are expected to be able to read, study and understand Arabic texts in the form of literature relating to their lectures.

Why is learning to use Arabic in Islamic subjects so important? This is due to the first: 1). The original sources of Islamic teachings (al-Qur'an and Hadith) are written in Arabic, 2). Other Islamic materials, such as Tafsir, hadith, Fiqh, Aqedah, tasawuf, etc. Also written in Arabic. 3). Islamic studies will have more weight and maximum if you take primary references in Arabic [1]

Indicators for the failure of lecturers to apply Arabic as the language of instruction in religious subjects are as follows: (1) students' skills in Arabic so far have not shown significant development (2) lectures in Islamic studies promised to use Arabic apparently does not occur (3) students do not boast of Arabic at all (4) Arabic lecturers do not like Arabic, the proof is that even though they teach Arabic, they never use it in daily conversation (5) funds used to finance this program is big enough but less productive (6) the program is positive (small), but the losses are big, for example there are lecturers who show insincerity, because the salary is small (7) in the present and future people can understand Islam without mastering Arabic, because a lot of books about Islam has been translated.

Besides the weaknesses above according to the writer's observation is due to the weakness of students' Arabic learning motivation caused by the lack of variety of methods and approaches made by lecturers in teaching Arabic and material that tends to be monotonous and less desirable to students, while currently there are various methods of teaching Arabic language, For example, grammar-translation method, direct method, reading method, oral-aural method, audiolingual method, and communicative approach / method [2]. Therefore, it is necessary to apply effective methods that can improve students' Arabic ability [3].

Ideally, intensive Arabic lecture programs are the foundation for religious courses in general, such as interpretation, hadith, figh and so on. After completing this intensive Arabic lecture program and they return to their respective majors, then with the ability of the Arabic language, they are expected to be able to read and study Arabic literature, then make it as an object of research and study, adjusted to the department and their respective fields [4].

But so far, according to observations of some circles, the Arabic language skills of the Sulthan Thaha Saifuddin State Islamic University of Jambi students that they obtained from the Arabic Language Lecture Program, have still not met their main objectives and have not yet been measured academically. Based on research conducted by several Arabic language lecturers, it shows that religious subjects are very few realized. This is because, based on the findings of the study, there has not been one major lecturer who explicitly applied Arabic as the language of instruction for religious subjects and only a few 
of them used Arabic literature as the main reference book in lectures on religious subjects.

In addition, based on preliminary observations of exam questions on religious materials, especially interpretations, hadith, fiqh and so on, it shows that none of the questions were written in Arabic even though the content of the material taught was filled with Arabic culture. There are even some questions related to linguistics in the Arabic department which are written in Indonesian.

From some of the facts presented above shows that the purpose of organizing Arabic lectures for a full year that costs a lot, mind and energy invested has not shown encouraging results, because it is necessary to conduct research on the effectiveness of using Arabic as the language of instruction in lecturing courses religion at the Sulthan Thaha Saifuddin State Islamic University of Jambi.

\section{METHODS}

In this study, the authors used a qualitative research approach. The type of research used in this study is case study which is located at the Sulthan Thaha Saifuddin State Islamic University of Jambi. This case study relies on data, facts and writer's findings from the field or research settings, namely the Sulthan Thaha Saifuddin State Islamic University of Jambi. These field data are also supported by relevant, valid and up-todate library theories to support research data. This research is a case study. The object of this research are religious lecturers and students of the Sulthan Thaha Saifuddin State Islamic University of Jambi who are taking religious courses, and people who are competent in the religious field at the Sulthan Thaha Saifuddin State Islamic University of Jambi.

This study has the characteristics of qualitative research in accordance with the opinion of Bogdan and Biklen which says that qualitative research has the following characteristics: (1) using natural settings as data sources and researchers as core instruments (2) are descriptive, (3) is more concerned with the process rather than the results, (4) analyzing data inductively, and (5) meaning is the main concern [5].

The types of data the authors use in this study consist of primary data and secondary data. Primary data is data taken directly from the original source without intermediaries. In compiling this study which included primary data were students and lecturers at the Sulthan Thaha Saifuddin State Islamic University of Jambi, and other academics, whereas secondary data is data taken indirectly from the source or through intermediaries [6]. Secondary data included in this study are historical documentation of the Sulthan Thaha Saifuddin State Islamic University of Jambi, data on the situation of students and lecturers, documentation of organizational structure, and documentation of facilities and infrastructure at the Sulthan Thaha Saifuddin State Islamic University of Jambi.

While the data sources used in this study are human and material sources [7]. Sources of data in the form of humans are some students and lecturers, while the source of material is administrative documentation, interviews, and author's observations. The data of this study are the answers of lecturers of religious subjects and students to interviews conducted by researchers [8]. The data of this study came from the results of participant observation by holding field notes and interviews with managers, lecturers, and students. The data is also in the form of lecturer's documents on Religious Courses such as annual, semester, monthly, weekly and learning evaluation results [9].

Based on the type of research the author uses, namely case study, then the techniques or procedures used in obtaining data are interviews, observation, documentation, and literature study. To collect this research data, researchers used several techniques, namely interviews, observation, and documentation [10].

The interview is used as a method to find argumentative data and explain the implementation of the use of Arabic as the language of instruction in religious subjects at the Sulthan Thaha Saifuddin State Islamic University of Jambi. This interview was conducted with lecturers, students and the authorities. In this process, the researcher accepts the reality as it is and acts as objectively as possible [11].

This observation method the author uses to obtain secondary data, such as observing the process of teaching and learning activities in the course of interpretation, hadith, fiqh at the Sulthan Thaha Saifuddin State Islamic University of Jambi. Observations made were participant observation. This observation technique is carried out to get a field note about the phenomena that occur significantly in the field [12]. The researcher accepts the statement as objectively as possible [13].

In the documentation technique, the writer collects the documents of lecturers of hadith courses such as hadith curriculum, annual program, semester program, weekly program, unit of study, teaching design and teaching evaluation results.

\section{RESULTS AND DISCUSSION}

\section{A. The Application of Arabic as Language of Introductory Lectures on Religious Subjects}

Based on the observations we made on several classes that we saw in the implementation of language lectures, the religious lectures at the Sulthan Thaha Saifuddin State Islamic University of Jambi showed that there were almost no lecturers of Religious Courses who used Arabic as the language of instruction in full; likewise, are lecturers who teach at Adab and Humanities. As for local religious lecturers the Sulthan Thaha Saifuddin State Islamic University of Jambi, no one uses Arabic as the full language of instruction, from the beginning of the lecture to the end of the lecture.

There are some lecturers who use Arabic as an opening lecture for Islamic courses, but after entering the material, they gradually change it to Indonesian until the end of the lecture. In 
fact, most lecturers, from the beginning of the lecture to the end of the lecture, always use Indonesian in teaching Islamic courses, although occasionally using Arabic, both at the beginning and end of the lecture.

Based on interviews we conducted with an open questionnaire to students participating in Islamic courses at the Faculty of Tarbiyah and Teacher Training, the students objected if religious lectures were delivered using Arabic for varied reasons. Most students disagree with this because their Arabic language skills are low and have forgotten after entering their respective majors. There are only a few students who agree with this program, because maybe he has adequate Arabic, both because of learning outcomes outside the dormitory and/or inside the dormitory.

In addition, based on the results of interviews conducted by researchers with Islamic lecturers, most of them said that they had a little difficulty facing students who were less able to grasp explanations in Arabic. If they are left just like that it will result in them being bored and not understanding anything, and if their abilities are to be followed, the learning material will fall behind and not meet the target. Therefore, to avoid all that, they prefer to use Indonesian rather than using Arabic as the language of instruction.

Based on our observations, there are several faculties that have tried to apply Arabic as the language of instruction for Islamic Lectures, mainly in Arabic and Ahwalu Syakhsyiyah majors. For both of these majors, it is only natural to make Arabic as the language of instruction for Islamic material, because these two majors have the highest rank in Arabic courses; for the Ahwalu Syakhsiyah department getting an average score of 3.62, which means that almost all of their students get an A grade and students majoring in Arabic have an average grade of 3.58 which means that more than $70 \%$ of them get an A.

As for the other majors, it shows that almost all of them have not made Arabic as the language of instruction in teaching Islamic subjects. However, there are some lecturers who have obliged their students to take direct references from Arabic books with a minimum of five titles, while the rest are only allowed to use Indonesian literature. However, there are not many lecturers who implement this lecture system, but only a few lecturers so that it cannot be considered as a trusted benchmark. On the contrary, most lecturers in religious subjects who have not made Arabic as the language of instruction and are not so strict in requiring their students to refer to books in Arabic are large enough and can be said to be the majority. This means that the objectives of learning Arabic at the Sulthan Thaha Saifuddin State Islamic University of Jambi have not been fully implemented.

\section{B. Models of Islamic Subject Learning}

1) Using Arabic in full. According to the observation of researchers that when in the teaching and learning process whose lecturers use Arabic as the language of instruction in Islamic Studies, many students complain and are bored when lecturers try to convey material in Arabic. Therefore, they ask lecturers to present it in two languages (bilingual), sometimes Arabic and sometimes Indonesian to add clarity to the material.

However, for lecturers from abroad, even though there may be students who don't understand, they still deliver their material in Arabic. However, according to the results of interviews conducted by researchers with these lecturers, they said that they were happy to teach at the Sulthan Thaha Saifuddin State Islamic University of Jambi, because students understood Arabic and they could catch what they were conveying even in Arabic.

2) Using Arabic in doing tasks. Based on our observations, another form of using Arabic as the language of instruction for Islamic Lectures at the Sulthan Thaha Saifuddin State Islamic University of Jambi is the existence of a number of Islamic lecturers who require their students to write lecture assignments and discussion papers in Arabic, while in lectures and discussions still use Indonesian.

3) Making Arabic literature as a reference requirement. Another form of the use of Arabic as the language of instruction for Islamic currency at the Sulthan Thaha Saifuddin State Islamic University of Jambi, based on observations made by researchers, is the presence of some Islamic currency lecturers who use Arabic literature as reference material in learning. Some lecturers at the Sulthan Thaha Saifuddin State Islamic University of Jambi require students to refer to original sources written in Arabic or English. In this case, there are those who require a minimum of five literatures for each paper and some are lacking.

4) Use Arabic in exam questions. Based on observations made by researchers of the learning process of Islamic currency at the Sulthan Thaha Saifuddin State Islamic University of Jambi is, there are lecturers who use Arabic as the language of the test both the Midterm and Midterm Exams. In this case, there have been many lecturers at the Sulthan Thaha Saifuddin State Islamic University of Jambi who practice it. According to the lecturer, he has used this method since a few semesters ago and according to him the students were able to answer the questions in Arabic, although nahwiyah still experienced many mistakes. However, there are also many who are less able to answer in Indonesian even though the problem is written in Arabic.

\section{Constraints in the use of Arabic as the language of instruction in Islamic subjects.}

1) Students' skill. Based on interviews conducted by researchers with several Islamic lecturers, such as interpretive lecturers and hadith, we found that the Arabic ability of students in one class is very varied. There are those who have high Arabic language skills, there are those who have medium abilities and there are also those who have low Arabic language skills, so it is difficult for lecturers to take action to apply Arabic as the language of instruction in lectures. That is 
because the grouping of classes in the majors is not based on the ability to speak Arabic, but they are grouped based on regular classes in the form of a package system. If Arabic is forced to be applied, it could be that students who have low language skills will have difficulty in capturing and understanding the content (material) of the lectures, so that their emphasis may not be on studying the lecture material, but on its linguistic aspects. Because of the varied abilities of students, most Islamic lecturers prefer Indonesian as the language of instruction in Islamic subjects.

2) Lecturers'skill. Based on observations of the process of teaching and learning activities in Islamic subjects, there are still some religious lecturers at the Sulthan Thaha Saifuddin State Islamic University of Jambi who do not master Arabic well. Those who belong to this group only master passive Arabic, while they are not actively accustomed or even have no ability at all, so making Arabic as the language of instruction is very impossible for them. Therefore, they prefer Indonesian as the language of instruction in Islamic material lectures rather than Arabic. But at the very least, they have encouraged their students to look for Arabic literature in accordance with the syllabus given to students. But in the lecture process, the language of instruction is still to use Indonesian and the books in Arabic are only used as a reference. The number of lecturers included in this group is actually not much, but they exist in almost all departments.

3) The lack of Arabic literature materials. Based on the observations of researchers, many lecturers and students complained about the lack of Arabic literature to be used as a reference for certain subjects. For the subjects of interpretation, hadith and figh, there may be sufficient Arabic literature available, but for other Islamic material such as Islamic Cultural History, Islamic Philosophy and so on it is very difficult to find Arabic literature. Even for the subjects of interpretation, hadith and fiqh, even if Arabic-language literature exists, the amount is still very minimal and may not be borrowed.

4) Accuracy in mastering abilities. Based on our findings, most of the lecturers have difficulty understanding the material of Islam in the course if delivered in Arabic directly, therefore many of them prefer to use Indonesian as the language of instruction, rather than using Arabic as a language of instruction. Many students themselves find it difficult to understand the language, let alone understand the contents of the material, so many of them are asking lecturers to repeat the explanation in Indonesian after the lecturer has said it in Arabic. This proves that the use of Arabic cannot be effective when seen from this principle.

If we look at the learning objectives, the learning objectives of religion, as stated by experts, are conscious efforts undertaken to carry out physical and spiritual guidance given by educators to the educated, so that after education is given, children can become Muslim people who can understand and practice the teachings of Islam in their lives and make Islam the way of life. If a student cannot master the content of the material taught by the lecturer, it will be very difficult for him to apply what he has gotten into his daily life. Not to mention when viewed from the side of cognitive mastery. it could be that most students will not understand the contents of the material because their concentration is only focused on mastering the language, not on the content.

Based on the results of an interview with a Shari'ah Faculty lecturer, students initially felt complained when told to do lectures using Arabic. However, after being forced, all students worked on the assignment as desired, even though many did not meet the writing standards. According to the lecturer of Islamic subject at the Faculty of Tarbiyah, that when given the choice to students to write papers in Arabic or English, apparently from the results of the papers collected, $80 \%$ of students write papers in English although it is strongly recommended to use Arabic. This means that students still have a lot of difficulties when they have to make or write lecture assignments using Arabic, even though they are able to carry out if forced. But again, students are trapped in linguistic material rather than Islamic material that they obtain.

5) Conformity with the procedure of learning activities that must be taken. According to some Islamic lecturers at the Sulthan Thaha Saifuddin State Islamic University of Jambi, the use of Arabic as the language of instruction actually does not violate the procedure of teaching and learning activities at all, because a material can be delivered in any language as long as the material can be understood by students clearly. Therefore, procedurally, the use of Arabic as the language of instruction in Islamic courses does not violate the procedures that exist in learning. Therefore, judging from this principle, as long as a lecturer has fulfilled the procedures stipulated in a study, the use of Arabic as the language of instruction for religious lecturers does not experience any deviation in teaching procedures

6) The quantity to work as a form of learning outcomes. In every Islamic course in the Sulthan Thaha Saifuddin State Islamic University of Jambi, the lecturers can conduct several types of activities, namely: lectures, making papers, making summaries, discussions, midterm exams and end semester exams. In connection with the principle of the quantity of this performance, according to a lecturer in the subject lecture Hadith at the Faculty of Tarbiyah said that almost all students work on the lecture assignments assigned to them, even though there are those who do it in Indonesian even though they are required to use Arabic. According to him, many students found it difficult to put their ideas into Arabic even though they could actually answer them. Therefore, when the lecturers of Islamic Studies in the Faculty of Humanities held examinations, whose questions were written in Arabic, many of the students answered in Indonesian because they found it difficult to express ideas and were very slow. Therefore, they 
chose to answer in Indonesian to accelerate the completion of the task rather than in Arabic. Viewed from this side, in terms of quantity students continue to do the tasks given by the lecturer in full, but the shape varies according to students' abilities. Therefore, from this point of view, the use of Arabic as the language of instruction does not experience significant problems, because every student can complete the assignments according to the required quantity.

7) The quality of the final results that can be achieved. One of the problems faced by Islamic lecturers at the Sulthan Thaha Saifuddin State Islamic University of Jambi when applying Arabic as the language of instruction is the difficulty of delivering material quickly and appropriately to students in general. Every time the lecturer submits an explanation in Arabic, students can always ask to return to the lecturer to repeat the explanation in Indonesian, so the lecturers must work twice in giving an explanation. Because the lecturers want students to understand, they also explain it again in Indonesian so that at the end of the lecture students understand the material being taught.

A lecturer stated that students' mastery of Islamic material taught in Arabic was lacking. That is because students are burdened by two things that they must catch together: first in terms of language and secondly in terms of content. If lecturers force themselves to deliver lectures in Arabic, then most students will have difficulty understanding the contents of the material, so lectures will be in vain.

In addition, based on the results of assignments given to students, according to a lecturer of Islamic Studies at the Sulthan Thaha Saifuddin State Islamic University of Jambi, if lecture assignments are given directly in the classroom, the results obtained by students are not so good, but if done outside the classroom (home), they can fulfill their tasks well even in Arabic. This means that in terms of quality, the results of Islamic subject teaching are delivered in Arabic as the language of instruction, less than the maximum. That is because the concentration of students when in the learning process is divided into two: first, the concentration of language or understanding the language itself they experience difficulties. Second, understand the material; If the material being taught is something old (repeating), it might not be so problematic, but if the material is completely new, then students will experience two difficulties (language and material) together.

In terms of the level of transfer of learning, the teaching of Islamic lectures using Arabic as the language of instruction is felt slower compared to lectures using Indonesian. Thus, as said above, because lecturers must repeat explanations and students understand the material more slowly than if delivered directly in Indonesian. If this kind of delay continues, then it could be the target material that has been set in the Islamic course syllabus in one semester cannot be achieved because students are slow in understanding the material, so the lecturer must repeat his explanation many times.

\section{CONCLUSION}

Conclusions for this research are: (1) Arabic as an introductory language. Islam at the Sulthan Thaha Saifuddin State Islamic University of Jambi still cannot be implemented to the fullest and only a few lecturers have started to implement it even though not in full. (2) Islamic lecture models that use Arabic as the language of instruction are very varied: (a) use Arabic fully (b) Use Arabic in making assignments (c) require students to refer directly to Arabic literature (d) use Arabic in middle and final test questions. (3) Constraints faced in the use of Arabic as the language of instruction in Islamic material at the Sulthan Thaha Saifuddin State Islamic University of Jambi can be classified into three things: (a) The constraints that come from students, namely because the Arabic language skills of students are very varied, and the grouping of regular classes is not based on language skills. (b) Constraints that come from lecturers, namely there are still some Islamic lecturers who do not have the ability to speak Arabic actively, so it is difficult for him to explain the material in Arabic. (c) Limited books and literature on Islamic Subjects in Arabic. (4) The implementation of Arabic as an introductory language. Islam at the Sulthan Thaha Saifuddin State Islamic University of Jambi, when viewed from the theory of learning effectiveness which is oriented to the process and results, it can be said to be ineffective, because both the process and the results achieved relating to the material being taught, still do not meet the requirements the effectiveness of learning that must be achieved results in a learning. (5) The material being taught still does not meet the requirements of learning effectiveness that must be achieved in a learning outcome.

\section{ACKNOWLEDGMENT}

I wish to express my sincere gratitude to the conference chair of AES 2020 Putu Indah Rahmawati, SST.Par, M. Bus., $\mathrm{Ph}$. D for providing me an opportunity to present and publish my research in The 5th Asian Education Symposium (AES) 2020 in Bali. I sincerely thank Prof. Dr. Lyn Parker (University of Western Australia), Dr. phil. Dessy Seri Wahyuni (Ganesha University of Education, Indonesia), Prof. Hiroyuki Miyake (University of Kitakyushu, Japan) as keynote speakers. I also thank the Executive Coordinator of UPI Postgraduate School Prof. Dr. Anna Permanasari, M.Si., and all of Committee for their guidance and encouragement in carrying this project work. I also wish to express my gratitude to the officials and other staff members of Indonesia University of Education (UPI) Bandung and Ganesha University of Education who rendered their help during the period of my project work.

I also thank the Director of Postgraduate Program the Sulthan Thaha Saifuddin State Islamic University of Jambi and Scientific Committee of the 5th Asian Education Symposium (AES) 2020 from UIN Jambi Prof. Dr. H. Ahmad Syukri, SS., M.Ag. and all of the staff members for providing me the opportunity to embark on this project. 


\section{REFERENCES}

[1] A. Andriani, "Urgensi Pembelajaran Bahasa Arab Dalam Pendidikan Islam," Ta'allum J. Pendidik. Islam, vol. 3, no. 1, pp. 39-56, 2015.

[2] S.-C. Chang, "A Contrastive Study of Grammar Translation Method and Communicative Approach in Teaching English Grammar," English Lang. Teach., vol. 4, no. 2, p. 13, 2011.

[3] S.C. Haron, "The Teaching Methodology of Arabic Speaking Skills: Learners' Perspectives.," Int. Educ. Stud., vol. 6, no. 2, pp. 55-62, 2013.

[4] A. Malik, "Education Management Ma'had Aly in Ulama Development at As' Adiyah Sengkang South Sulawesi,” Int. J. Soc. Sci., vol. 67, no. 1, 2018.

[5] K. V Cowles, "Issues in Qualitative Research on Sensitive Topics," West. J. Nurs. Res., vol. 10, no. 2, pp. 163-179, 1988.

[6] E. Cox, B.C. Martin, T. Van Staa, E. Garbe, U. Siebert, and M.L. Johnson, "Good Research Practices for Comparative Effectiveness Research: Approaches to Mitigate Bias and Confounding in the Design of Nonrandomized Studies of Treatment Effects Using Secondary Data Sources: The International Society for Pharmacoeconomics and Outcomes Research Good Research Practices for Retrospective
Database Analysis Task Force Report-Part II," Value Heal., vol. 12, no. 8, pp. 1053-1061, 2009

[7] E.S. Shernoff, T.G. Mehta, M.S. Atkins, R. Torf, and J. Spencer, "A Qualitative Study of the Sources and Impact of Stress among Urban Teachers," School Ment. Health, vol. 3, no. 2, pp. 59-69, 2011.

[8] S. Talmy, "Qualitative Interviews in Applied Linguistics: From Research Instrument to Social Practice,” Annu. Rev. Appl. Linguist., vol. 30, p. 128, 2010.

[9] C. Coffin, M.J. Curry, S. Goodman, A. Hewings, T. Lillis, and J. Swann, Teaching academic writing: A toolkit for higher education. Routledge, 2005.

[10] S.C. Kitto, J. Chesters, and C. Grbich, "Quality in Qualitative Research,” Med. J. Aust., vol. 188, no. 4, pp. 243-246, 2008.

[11] Y. Marselina, P. Le-Clech, R.M. Stuetz, and V. Chen, "Characterisation of Membrane Fouling Deposition and Removal by Direct Observation Technique," J. Memb. Sci., vol. 341, no. 1-2, pp. 163-171, 2009.

[12] S. Jamshed, "Qualitative Research Method-Interviewing and Observation,” J. basic Clin. Pharm., vol. 5, no. 4, p. 87, 2014.

[13] L. Baker, "Observation: A Complex Research Method," Libr. Trends, vol. 55, no. 1, pp. 171-189, 2006. 